\title{
NITRIC OXIDE INTERFERES WITH HYPOXIA SIGNALING DURING COLONIC INFLAMMATION
}

\author{
Cintia Rabelo e Paiva CARIA, Camila Henrique MOSCATO, Renata Bortolin Guerra TOMÉ, \\ José PEDRAZZOLI Jr, Marcelo Lima RIBEIRO and Alessandra GAMBERO
}

\begin{abstract}
Context - Intestinal inflammation can induce a local reduction in oxygen levels that triggers an adaptive response centered on the expression of hypoxia-inducible factors (HIFs). Nitric oxide, a well-described inflammatory mediator, may interfere with hypoxia signaling. Objectives - We aimed to evaluate the role of nitric oxide in hypoxia signaling during colonic inflammation. Method - Colitis was induced by single (acute) or repeated (reactivated colitis) trinitrobenzenosulfonic acid administration in rats. In addition, one group of rats with reactivated colitis was also treated with $\mathrm{N} \omega$-Nitro-L-arginine methyl ester hydrochloride to block nitric oxide synthase. Colitis was assessed by macroscopic score and myeloperoxidase activity in the colon samples. Hypoxia was determined using the oxygen-dependent probe, pimonidazole. The expression of HIF-1 $\alpha$ and HIF-induced factors (vascular endothelial growth factor - VEGF and apelin) was assessed using Western blotting. Results - The single or repeated administration of trinitrobenzenosulfonic acid to rats induced colitis which was characterized by a high macroscopic score and myeloperoxidase activity. Hypoxia was observed with both protocols. During acute colitis, HIF-1 $\alpha$ expression was not increased, but VEGF and apelin were increased. HIF-1 $\alpha$ expression was inhibited during reactivated colitis, and VEGF and apelin were not increased. $\mathrm{N} \omega$-Nitro-L-arginine methyl ester hydrochloride blockade during reactivated colitis restored HIF-1 $\alpha$, VEGF and apelin expression. Conclusions - Nitric oxide could interfere with hypoxia signaling during reactivated colitis inflammation modifying the expression of proteins regulated by HIF-1 $\alpha$.
\end{abstract}

HEADINGS - Colitis. Hypoxia-inducible factor 1. Nitric oxide. NG-Nitroarginine methyl ester. Endothelial growth factors.

\section{INTRODUCTION}

Inflammatory bowel disease (IBD) is a term that describes different pathologies, such as ulcerative colitis and Crohn's disease. Inflammation is thought to develop due to the breakdown of the intestinal epithelial barrier, which is accompanied by the subsequent exposition of luminal antigens to the mucosal immune system, resulting in the recruitment of inflammatory cells, such as neutrophils and monocytes. The cellular recruitment and local active inflammation reduce the availability of oxygen, leading to hypoxia ${ }^{(6)}$.

Hypoxia triggers an adaptive response in which the expression of hypoxia-inducible factors (HIFs) plays a central role. HIFs are believed to confer a protective response through the HIF-dependent induction of barrier-protective genes in the epithelium $^{(10)}$. Under hypoxic conditions, genes that are related to angiogenesis, such as vascular endothelial growth factor (VEGF), or to cellular proliferation, such as apelin, are induced ${ }^{(11)}$. The apoptotic effects of tumor necrosis factor $(\mathrm{TNF}-\alpha)$ were also inhibited by hypoxia ${ }^{(13)}$. However, hypoxia and inflammation are interdependent phenomena; hypoxia can elicit local inflammation, and inflammation can induce local hypoxia, as mentioned previously.

Decreases in oxygen need to be detected by cells in the hypoxic environment to induce the appropriate response. When oxygen levels are sufficient, prolyl hydroxylases (PHDs) hydroxylate and degrade the $\alpha$ subunit of HIF via ubiquitylation ${ }^{(14)}$. Nitric oxide (NO) displays many similarities to oxygen and may interfere with oxygen sensing mechanisms, as well as with hypoxia signaling ${ }^{(19)}$. The increased synthesis of NO via inducible nitric oxide synthase (iNOS) is a well-described event that occurs during intestinal inflammation $^{(20)}$.

Thus, we decided to evaluate the role of NO in hypoxia signaling during colonic inflammation using a well-established experimental model, trinitrobenzenosulfonic acid (TNBS)-induced colitis, and two different administration protocols in rats: single (acute colitis) and repeated (reactivated colitis). Single administration of TNBS is the protocol most often 
used in the literature but, repeated administration of TNBS provides a better correlation between experimental and clinical findings because of its ability to replicate relapse and remission periods that are frequent in Cronh's disease patients.

\section{METHOD}

\section{Animals}

Specific pathogen-free male Wistar rats (200-250 g, 6-8 weeks old) were obtained from the Multidisciplinary Center for Biological Research (State University of Campinas, Campinas, SP, Brazil). The experiments were performed in accordance with the principles outlined by the National Council for the Control of Animal Experimentation (CONCEA, Brazil), and received approval from the Ethics Committee of São Francisco University, Bragança Paulista, SP, Brazil (Protocol 002.09.09). The rats were maintained in a room with controlled humidity and temperature in collective cages and were exposed to 12 hour light-dark cycles. Twelve hours prior to an experiment, the animals were deprived of food (standard chow), but not water. The studies were carried out using 5-7 rats per group and in a first round four groups were performed: control of acute colitis, control of reactivated colitis, acute colitis and reactivated colitis. In a second round of experiments another three groups were performed: control of reactivated colitis treated with saline, reactivated colitis treated with saline and reactivated colitis treated with $\mathrm{N} \omega$-Nitro-L-arginine methyl ester hydrochloride (L-NAME) with five rats per group.

\section{TNBS-induced colitis}

The animals were anesthetized using ketamine/xylazine $(1: 1 \mathrm{v} / \mathrm{v})$, and colitis was induced by the intracolonic instillation of TNBS, either $10 \mathrm{mg}$ on day 0 (acute colitis group) or 3 mg on days 0,14 and 28 (reactivated colitis group), dissolved in $0.3 \mathrm{~mL}$ of $50 \%$ ethanol (Sigma, St. Louis, MO, USA). The solution was injected into the colon $8 \mathrm{~cm}$ proximal to the anus using a catheter. The instillation procedure lasted only a few seconds, and the rats were maintained in a vertical position until they had recovered from the anesthesia. The rats from the acute colitis group were sacrificed on the 7th day, and the rats from the reactivated colitis group were sacrificed on the 35th day under overdose of ketamine/xylazine (1:1 $\mathrm{v} / \mathrm{v})$. The control rats received saline via the same route of administration (control group).

\section{L-NAME treatment}

An additional group of TNBS-induced colitic rats with reactivation was treated with $\mathrm{N \omega}$-Nitro-L-arginine methyl ester hydrochloride (L-NAME; $10 \mathrm{mg} / \mathrm{kg} /$ day) intraperitoneally during the last 7 days of the protocol described above. Healthy and colitis controls were carried out and, rats received saline instead of L-NAME as described.

\section{Colitis characterization by macroscopic damage and myeloperoxidase activity}

The colons were immediately removed from the animals, opened longitudinally and evaluated for macroscopically visible damage by two observers who were unaware of the experimental groups. The criteria for the assessment of the macroscopic colonic damage of each animal were as follows: no damage (no points), hyperemia without any ulcers (1 point), linear ulcer with no significant inflammation (2 points), linear ulcer with inflammation at one site (3 points), two or more sites of ulceration/inflammation (4 points) and two or more major sites of ulceration and inflammation or one site of ulceration/inflammation extending $1 \mathrm{~cm}$ along the length of the colon (5 points). If the damage extended $2 \mathrm{~cm}$ along the length of the colon, the score was increased by 1 point for each additional centimeter of involvement (6-10 points).

Colon samples obtained longitudinally from a site of macroscopically detectable inflammation (or a corresponding site in the tissue with no macroscopically detectable inflammation) were homogenized in $0.5 \%(\mathrm{w} / \mathrm{v})$ hexadecyltrimethylammonium bromide in $50 \mathrm{mM}$ potassium phosphate buffer, $\mathrm{pH}$ 6.0. For the myeloperoxidase (MPO) assay, $50 \mu \mathrm{L}$ of each sample was added to $200 \mu \mathrm{L}$ of o-dianisidine solution $(0.167$ $\mathrm{mg} / \mathrm{mL}$ o-dianisidine dihydrochloride and $0.0005 \%$ hydrogen peroxide in $50 \mathrm{mM}$ phosphate buffer, $\mathrm{pH} 6.0$ ) immediately prior to reading the change in absorbance at $460 \mathrm{~nm}$ over a 5 min period using a microplate reader (Multiscan MS, Labsystems, Joensuu, Finland).

\section{Pimonidazole staining}

To assess colonic hypoxia during colitis induced TNBS administration, rats were treated intraperitoneally with 60 $\mathrm{mg} / \mathrm{kg}$ pimonidazole $1 \mathrm{~h}$ prior to sacrifice. Following the manufacturer's recommended instructions, colonic pimonidazole distribution was visualized on paraffin-embedded sections using a Hypoxyprobe Omni Kit (Natural Pharmacia International Inc., Massachusetts, USA).

\section{TNF- $\alpha$ measurements and Western blot analysis}

To measure TNF- $\alpha$ using an enzymatic assay (EIA), colon samples were collected as previously described, excised and immediately homogenized in solubilizing buffer at $4^{\circ} \mathrm{C}(1 \%$ Triton X-100, $100 \mathrm{mM}$ Tris-HCl, $100 \mathrm{mM}$ sodium pyrophosphate, $100 \mathrm{mM}$ sodium fluoride, $10 \mathrm{mM}$ EDTA, $10 \mathrm{mM}$ sodium orthovanadate, $2 \mathrm{mM}$ PMSF and $0.1 \mathrm{mg}$ of aprotinin/ $\mathrm{ml})$. The insoluble material was removed by centrifugation for $20 \mathrm{~min}$ at $9,000 \mathrm{~g}$ and $4^{\circ} \mathrm{C}$. The protein concentrations of the supernatants were determined using the Biuret method. TNF- $\alpha$ was quantified using a commercially available kit (R\&D Systems, Minneapolis, MN, USA).

For the protein analysis via Western blotting, the supernatant aliquots were treated with Laemmli sample buffer containing $100 \mathrm{mM}$ dithiothreitol and heated in a boiling water bath for $5 \mathrm{~min}$, after which the samples were subjected to SDSPAGE in a Bio-Rad miniature slab gel apparatus (Mini-Protean). For the WB experiments, $0.15 \mathrm{mg}$ of the protein extract from each tissue was separated using SDS-PAGE, transferred to nitrocellulose membranes and blocked for 2 hours with blocking buffer ( $5 \%$ blocking agent, GE Healthcare, UK) in 
a Tris buffered solution. The membranes were then incubated overnight with anti-iNOS (sc-8310), anti-VEGF (sc-507), anti-HIF-1 $\alpha$ (sc-10790) and anti-apelin (sc-33804) antibodies at dilutions of 1:1000 (Santa Cruz Biotechnology, Inc., CA, USA). The nitrocellulose membranes were developed using commercially available chemiluminescence kits (GE Healthcare, UK). The band intensities were quantified by the optical densitometry (Scion Image software, ScionCorp, Frederick, $\mathrm{MD)}$ of the developed autoradiography.

\section{Statistical analysis}

All of the data are expressed as the means \pm Standard Error of the Mean (SEM). Non-parametric data were expressed as the medians. The comparisons between groups of data were performed using unpaired Student's test. Statistical analysis were performed using GraphPad InStat (GraphPad Software, La Jolla, CA, USA). An associated probability ( $P$ value) of less than $5 \%$ was considered significant.

\section{RESULTS}

\section{Colitis assessments}

The single or repeated administration of TNBS in alcoholic vehicle influenced both hyperemia and the number of small ulcers that were observed macroscopically, resulting in a higher macroscopic score (Figures 1B and 2B). Colonic inflammation decreased body weight gain during acute or reactivated colitis, as shown in Figures 1A and 2A, respectively. Myeloperoxidase (MPO) activity, a biochemical marker of neutrophil infiltration, was also higher in the colons of colitic rats (Figures 1C and 2C).

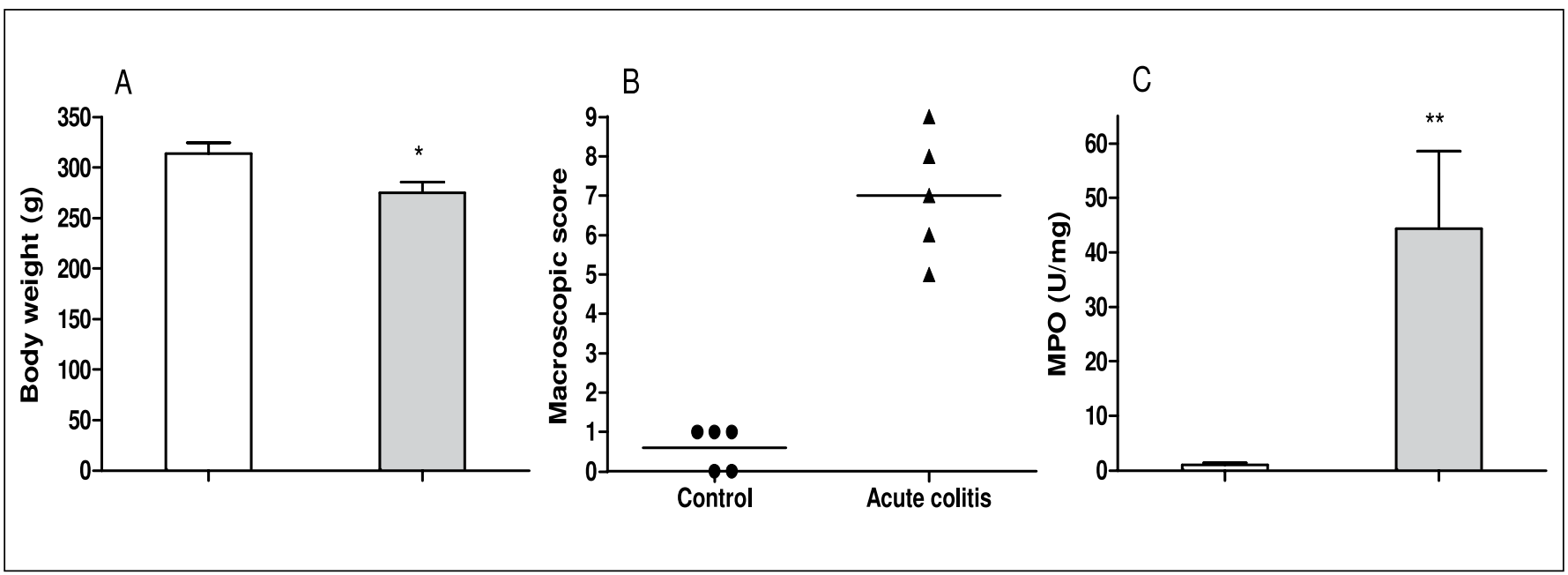

FIGURE 1. Body weight (A), macroscopic score (B) and myeloperoxidase (MPO) activity (C) in colon after 7 days of one trinitrobenzenosulfonic acid (TNBS) administration to rats (Acute colitis). A and C. Data are expressed as the mean \pm SEM of five rats. $* P<0.05$ and $* * P<0.01$ when compared with control group. B. Data are expressed as medians $(n=5)$.

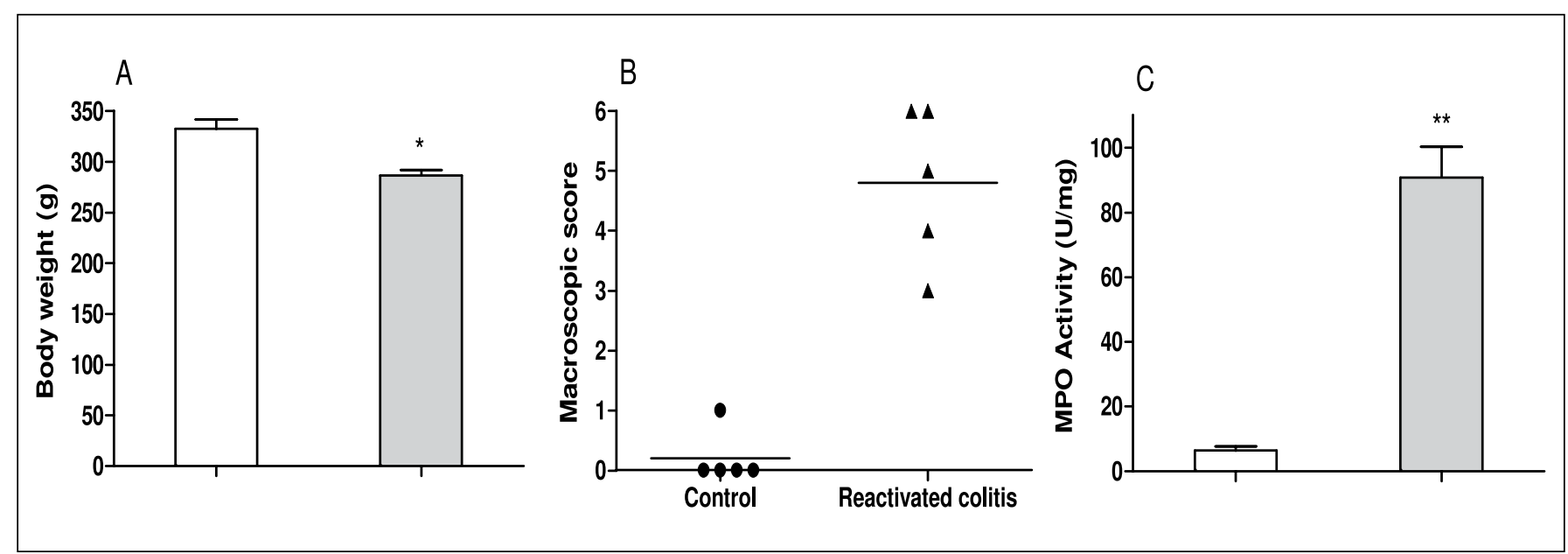

FIGURE 2. Body weight (A), macroscopic score (B) and myeloperoxidase (MPO) activity (C) in colon after repeated trinitrobenzenosulfonic acid (TNBS) administration to rats (Reactivated colitis). A and C. Data are expressed as the mean \pm SEM of five rats. $* P<0.05$ and $* * P<0.01$ when compared with control group. B. Data are expressed as medians $(n=5)$. 


\section{HIF-1 $\alpha$ expression during TNBS-induced colitis}

HIF-1 $\alpha$ protein expression was similar in the colons of rats in the control and acute colitis groups, but VEGF and apelin expression were higher in the colons of rats in the acute colitis group compared to the control group (Figures 3A, $\mathrm{B}$ and C). In contrast, HIF-1 $\alpha$ expression was lower in the colons of reactivated colitis group compared to the controls
(Figure 4A). Apelin and VEGF expression in the colons of rats with reactivated colitis were not altered (Figures 4B and C). iNOS expression was induced by intestinal inflammation in both groups (Figures 3D and 4D), but the increase was more pronounced in the reactivated colitis group (a 1.44-fold increase was observed in the acute colitis group versus a 5.25fold increase in the reactivated colitis group).

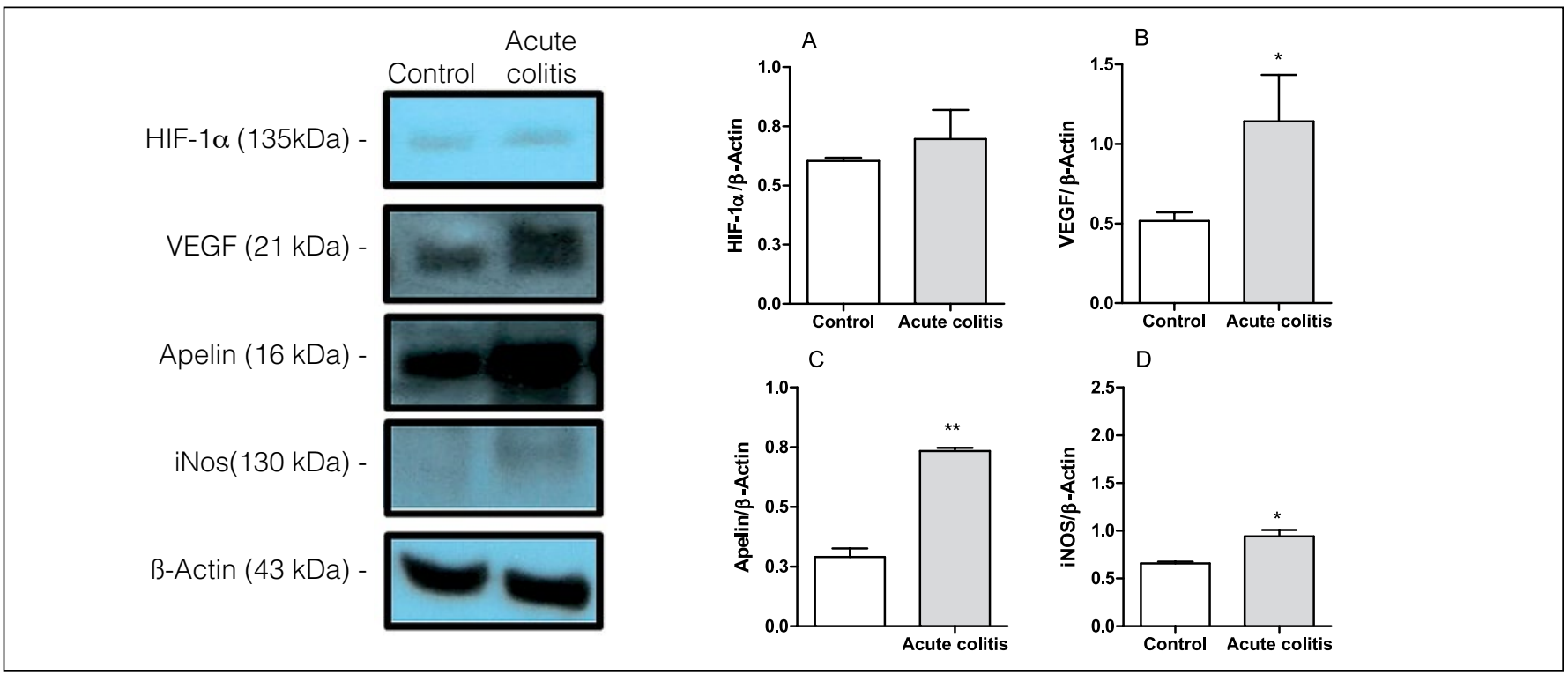

FIGURE 3. Levels of HIF-1 $\alpha$ (A), vascular endothelial growth factor (VEGF) (B), apelin (C) and inducible nitric oxide synthase (iNOS) (D) in rat colon from control and colitis after one trinitrobenzenosulfonic acid (TNBS) administration (Acute colitis). Western blot analysis was performed on colon protein extracts with antibodies against HIF-1 $\alpha$, VEGF, apelin, iNos and $\beta$-actin. The blot images are representative of one experiment. Bars show the densitometry quantification of HIF-1 $\alpha$, VEGF, apelin, and iNos levels, normalized by densitometry quantification of $\beta$-actin level for the same sample. Data are expressed as the mean \pm SEM of three experiments. $* P<0.05$ and $* * P<0.01$ when compared with control group.

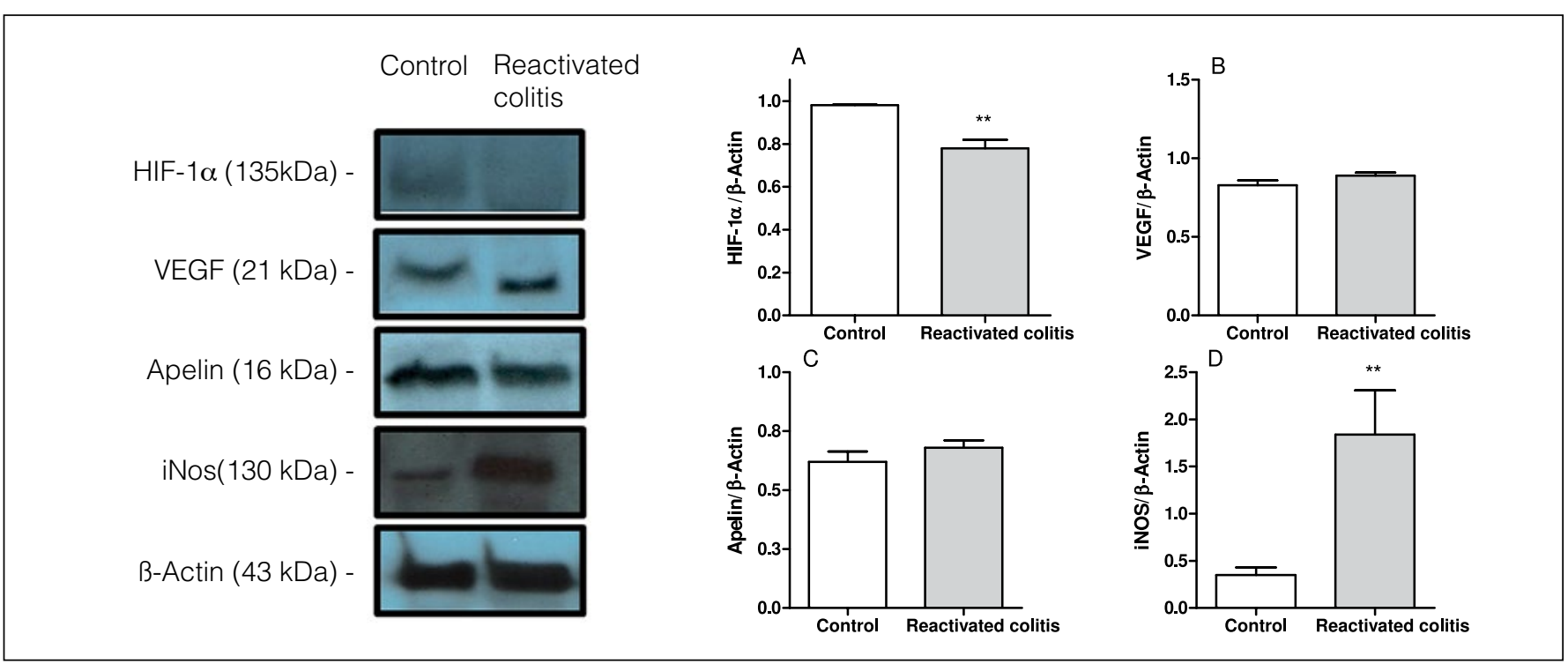

FIGURE 4. Levels of HIF-1 $\alpha$ (A), vascular endothelial growth factor (VEGF) (B), apelin (C) and inducible nitric oxide synthase (iNOS) (D) in rat colon from control and colitis after repeated trinitrobenzenosulfonic acid (TNBS) administration (Reactivated colitis). Western blot analysis was performed on colon protein extracts with antibodies against HIF-1 $\alpha$, VEGF, apelin, iNos and $\beta$-actin. The blot images are representative of one experiment. Bars show the densitometry quantification of HIF-1 $\alpha$, VEGF, apelin, and iNos levels, normalized by densitometry quantification of $\beta$-actin level for the same sample. Data are expressed as the mean \pm SEM of three experiments. $* * P<0.01$ when compared with control group. 


\section{Hypoxia during TNBS-induced colitis}

To determine the presence of hypoxia during TNBS-induced colitis, we evaluated the binding of pimonidazole to macromolecules, which occurs in the absence of adequate oxygen levels. Consistent with earlier reports, physiologic hypoxia on the colonic surface epithelium was observed in healthy animals (control group, Figure 5A). Following the induction of colitis by the single or repeated administration of TNBS (Figure 5), increased colonic epithelial pimonidazole uptake, extending to additional parts of the crypts and the submucosal layer, was observed in the model of reactivated colitis.

\section{Effects of L-NAME treatment on reactivated colitis}

L-NAME treatment during the final 7 days of the experiment (after the final TNBS administration in the reactivation protocol) reduced the number of macroscopically observed lesions $(P=0.0571)$. However, MPO activity was not significantly reduced (Table 1 ) in colitic rats that received only saline i.p. Body weight gain and TNF- $\alpha$ were not improved after L-NAME treatment compared with the colitic group (Table 1).
TABLE 1. Macroscopic evaluation, myeloperoxidase (MPO) acitivity, body weight and cytokine production by colon tissue in control treated with saline (Control), colitis with reactivation/treated with saline (Colitis) and colitis with reactivation treated with L-NAME (Colitis + L-NAME),

\begin{tabular}{lccc}
\hline & Control & Colitis & $\begin{array}{c}\text { Colitis + } \\
\text { L-NAME }\end{array}$ \\
\hline Damage score & $0.2 \pm 0.2$ & $5.7 \pm 0.8^{* *}$ & $3.5 \pm 0.2^{\mathrm{a}}$ \\
MPO activity (U/g tissue) & $1.6 \pm 0.5$ & $6.7 \pm 2.3^{*}$ & $3.5 \pm 2.4$ \\
Final body weight $(\mathrm{g})$ & $385 \pm 10$ & $381 \pm 7$ & $358 \pm 14$ \\
Body weight gain $(\%)$ & $33.3 \pm 3.4$ & $18.8 \pm 1.8^{* *}$ & $18.1 \pm 1.8$ \\
TNF- $\alpha$ (pg/mg protein) & $0.8 \pm 0.3$ & $3.0 \pm 0.8^{*}$ & $4.4 \pm 0.3^{*}$ \\
\hline
\end{tabular}

$* P<0.05$ and $* * P<0.01$ when compared control versus colitis group $(\mathrm{n}=4-5) .{ }^{a} P=0.0571$ when compared colitis/L-NAME with colitis group.

After L-NAME treatment, colitic animals displayed higher levels of HIF-1 $\alpha$, apelin and VEGF expression (Figures 6A, B and C). iNOS expression was not reduced by L-NAME treatment (data not shown).
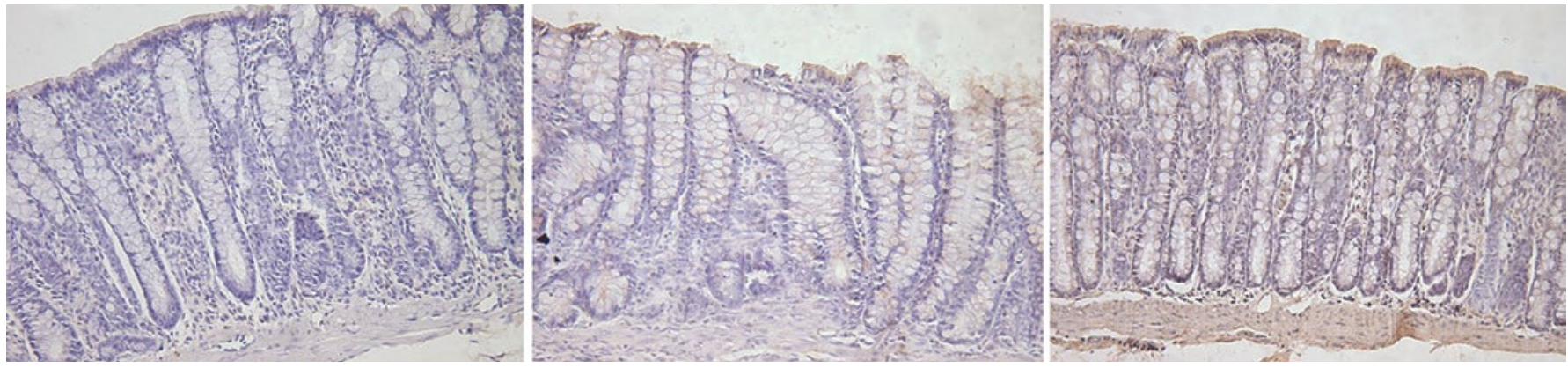

FIGURE 5. Pimonidazole-stained colonic sections from the control (A), acute colitis (B) and reactivated colitis (C) groups. Note the enhanced mucosal epithelial hypoxia that occurred during colitis. $5.0 \mathrm{~mm}$; magnification: 100x.

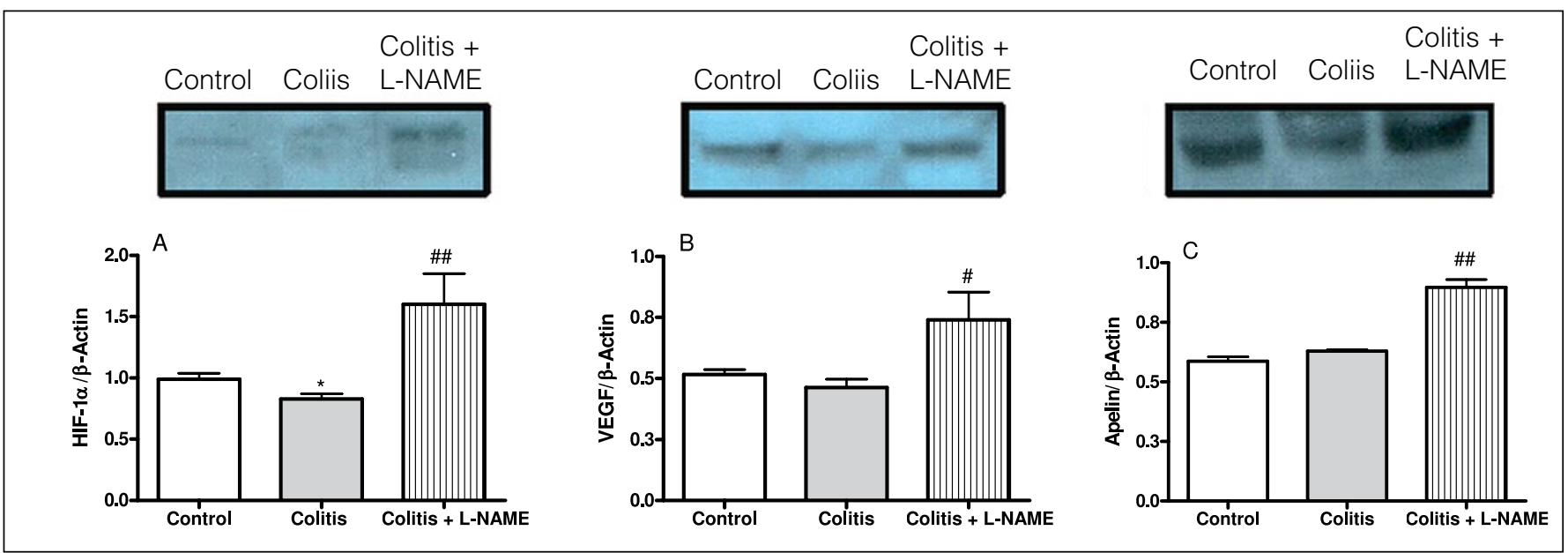

FIGURE 6. Levels of HIF-1 $\alpha$ (A), vascular endothelial growth factor (VEGF) (B) and apelin (C) in the colon of rats from the control treated with saline (Control), repeated trinitrobenzenosulfonic acid (TNBS) administration colitis treated with saline (Colitis) and repeated TNBS administration colitis treated with L-NAME (Colitis + L-NAME) groups. Western blot analysis were performed on the colon protein extracts using antibodies that had been raised against HIF- $1 \alpha$, VEGF, apelin and $\beta$-actin. The blot images are representative of one experiment (the $\beta$-actin figure is not shown). The bars show the densitometric quantifications of HIF-1 $\alpha$, VEGF and apelin levels after normalization by the densitometric quantification of the $\beta$-actin level for the same samples. The data are expressed as the mean \pm SEM of three experiments.

* $P<0.05$ compared to the control group. ${ }^{\#} P<0.05$ and ${ }^{\# \#} P<0.01$ when compared to the colitis group. 


\section{DISCUSSION}

Active mucosal inflammation is characterized by alterations in tissue metabolism and perfusion, resulting in hypoxia. Local hypoxia triggers an adaptive response that is focused on HIF-1 $\alpha$ expression. Karhausen and colleagues demonstrated the presence of hypoxia, both in the superficial mucosa and the deeper submucosal regions, using an imidazole dye after 7 days of TNBS administration in mice ${ }^{(15)}$. The expression of HIF-1 $\alpha$ and HIF- $1 \alpha$-regulated gene products was increased in these mice $^{(15)}$. In rats, hypoxia was observed 7 days after the administration of a single dose of TNBS, but increases in HIF-1 $\alpha$ were not observed. However, proteins that are regulated by HIF-1 $\alpha$, such as VEGF and apelin ${ }^{(10,11)}$ were increased in the colons of these animals. Interestingly, we observed that after repeated TNBS administration, a model that provides periods of relapse and remission ${ }^{(8)}$, HIF-1 $\alpha$ protein expression was lower in the colons of colitic rats than in healthy animals, despite the presence of hypoxia, as indicated by pimonidazole staining. Analysis of apelin and VEGF protein expression (HIF-1 $\alpha$-regulated factors) in colonic tissue revealed that they were not altered during reactivated colitis. Both of the TNBS-induced colitis protocols that were applied in this study induced inflammation and hypoxia, although in the colitis with reactivation model, hypoxia seemed to be more intense, affecting areas of the submucosa, but was not accompanied by hypoxia signaling. In the repeated administration protocol, iNOS was expressed at high levels, suggesting that higher NO production occurred in this experimental model. NO is considered to be an inflammatory mediator during IBD $^{(24)}$. NO can interfere with cell signaling and affect HIF- $1 \alpha$ activation via different mechanisms, but much of the current knowledge of $\mathrm{NO}$ was acquired using NO-donor compounds in vitro ${ }^{(1,3)}$. Under normoxic conditions, low concentrations of NO facilitate HIF-1 $\alpha$ degradation and impair HIF- $1 \alpha$ signaling, while high concentrations of NO stabilize HIF- $1 \alpha$ and mimic a hypoxic response ${ }^{(18)}$. However, NO inhibits HIF-a activation during hypoxia by inducing PHD transcription and increasing the bioavailability of free cellular iron, which is a co-factor for PHD activity ${ }^{(2,16)}$. In addition, NO can interact with cytochrome c oxidase $(\mathrm{CcO})$ and modulate its activity when $\mathrm{O}_{2}$ concentrations are low and the enzyme is in a reduced state $^{(25)}$. In this state, $\mathrm{O}_{2}$ utilization by the mitochondrial chain is reduced and free $\mathrm{O}_{2}$ can induce the PHD-mediated degradation of HIF-1 $\alpha^{(25)}$, resulting in inadequate cellular signaling during hypoxia. L-NAME administration to rats with TNBS-induced colitis with reactivation at a dose previously described to block NO synthesis in vivo ${ }^{(4,5)}$, improved HIF-1 $\alpha$ expression and increased apelin and VEGF protein expression. These results suggest that iNOS inhibition restored HIF- $1 \alpha$ signaling during intestinal inflammation and that this restoration was not dependent on an anti-inflammatory response induced by L-NAME. In addition, HIF-1 $\alpha$ expression did not induce a robust anti-inflammatory response because a reduction in macroscopic damage, but not in TNF- $\alpha$ or MPO levels, was observed. The role of HIF-1 $\alpha$ signaling in experimental models of colitis is controversial. Chronic increases in HIF signaling by the disruption of von Hippel-Lindau tumor suppressor protein (VHL) in mice trigger colonic inflammation and potentiate dextran sodium sulfate (DSS)-induced colitis ${ }^{(23)}$. However, the use of a PHD inhibitor (FG-4497), which stabilizes HIF-1 $\alpha$, had a beneficial influence on weight loss, histological modifications and TNF- $\alpha$ production in a murine model of TNBS-induced colitis $^{(21)}$. T-cells that infiltrated the inflamed mucosa in IBD patients expressed more HIF- $1 \alpha$, and HIF- $1 \alpha$ KO mice displayed more severe DSS-induced colonic inflammation ${ }^{(12)}$. Based on these positive reports, PHD inhibitors have been suggested for use as a potential therapeutic approach to treat IBD patients ${ }^{(7)}$. However, infliximab (an anti-TNF- $\alpha$ therapy) has demonstrated positive results by inhibiting angiogenic processes through VEGF-A inhibition in IBD patients ${ }^{(22)}$. The results of the present study demonstrated that HIF- $1 \alpha$ expression is variable in different experimental models of TNBS-induced colitis, despite the presence of hypoxia, and that iNOS inhibition restored HIF-1 $\alpha$ expression in TNBS-induced colitis with reactivations, suggesting that NO potentially interferes with hypoxia signaling during intestinal inflammation. iNOS expression and rectal NO levels were upregulated during active IBD $^{(17)}$ and were able to modulate the expression of several genes involved in perpetuating the inflammatory response ${ }^{(9)}$ indicating that NO is an important mediator of intestinal inflammation.

\section{CONCLUSIONS}

Nitric oxide interferes with hypoxia signaling during experimental models of TNBS-induced colitis and inhibits expression of HIF-1 $\alpha$ regulated proteins, having an important role in colitis pathogenesis. 
Caria CRP, Moscato CH, Tomé RBG, Pedrazzoli Jr. J, Ribeiro ML, Gambero A. A interferência do óxido nítrico na sinalização da hipóxia durante a inflamação colônica. Arq Gastroenterol. 2014,51(4):302-8.

ABSTRACT - Contexto - A inflamação intestinal pode induzir uma redução local nos níveis de oxigênio e ativar uma resposta adaptativa relacionada à expressão de fatores induzíveis por hipóxia (HIFs). O óxido nítrico, um mediador inflamatório bem descrito, pode interferir com a sinalização de hipóxia. Objetivos - O objetivo foi avaliar o papel do óxido nítrico na sinalização de hipóxia durante a inflamação colônica. Método - A colite foi induzida em ratos pela administração única (aguda) ou repetida (com reativações) de ácido trinitrobenzenosulfônico. Adicionalmente, um grupo de ratos de colite com reativações foi também tratado com N $\omega$-Nitro-L-arginina metil éster para inibir a óxido nítrico sintase. A colite foi avaliada através do escore macroscópico e da atividade de mieloperoxidase em amostras de cólon. A hipóxia foi determinada usando uma sonda dependente de oxigênio, o pimonidazol. A expressão de HIF-1 $\alpha$ e de fatores induzidos pelo HIF (factor de crescimento endotelial vascular - VEGF e apelina) foi avaliada pela técnica de Western blotting. Resultados - A administração única ou repetida de ácido trinitrobenzenosulfônico a ratos induziu colite que foi caracterizada por um alto escore macroscópico e alta atividade de mieloperoxidase. Hipóxia foi observada em ambos os protocolos. Durante a colite aguda, a expressão de HIF-1 $\alpha$ não aumentou, enquanto a de VEGF e apelina aumentou. A expressão de HIF-1 $\alpha$ esteve inibida durante a colite com reativações e, a expressão de VEGF e apelina não se modificou. O bloqueio com N $\omega$-Nitro-L-arginina metil éster durante a colite com reativações restabeleceu a expressão de HIF-1 $\alpha$, VEGF e apelina. Conclusões - O óxido nítrico interfere com a sinalização da hipóxia durante a colite com reativações modificando a expressão de proteínas que são reguladas pelo HIF-1 $\alpha$.

DESCRITORES - Colite. Fator 1 induzível por hipóxia. Óxido nítrico. NG-Nitroarginina metil éster. Fatores de crescimento endotelial.

\section{REFERENCES}

1. Ball KA, Nelson AW, Foster DG, Poyton RO. Nitric oxide produced by cytochrome C oxidase helps stabilize hif-1alpha in hypoxic mammalian cells. Biochem Biophys Res Commun. 2012;420:727-32.

2. Berchner-Pfannschmidt U, Tug S, Trinidad B, Oehme F, Yamac H, Wotzlaw C, et al. Nuclear oxygen sensing: induction of endogenous prolyl-hydroxylase 2 activity by hypoxia and nitric oxide. J Biological Chem. 2008;283:31745-53.

3. Brüne B, Zhou J. The role of nitric oxide (NO) in stability regulation of hypoxia inducible factor-1alpha (HIF-1alpha). Curr Medicinal Chemistry. 2003;10:845-55.

4. Chaves HV, Ribeiro R de A, De Souza AM, Rodrigues e Silva AA, Gomes AS Vale ML, et al. Experimental model of zymosan-induced arthritis in the rat temporomandibular joint: role of nitric oxide and neutrophils. J Biomed Biotechnol. 2011;2011:707985.

5. Cheng S, Yan Wm, Yang B, Shi JD, Song MM, Zhao Y. A Crucial role of nitric oxide in acute lung injury secondary to the acute necrotizing pancreatitis. Hum Exp Toxicol. 2010;29:329-37.

6. Colgan SP, Taylor CT. Hypoxia: an alarm signal during intestinal inflammation. Nat Rev Gastroenterol Hepatol. 2010;7:281-7.

7. Cummins EP, Doherty GA, Taylor CT. Hydroxylases as therapeutic targets in inflammatory bowel disease. Lab Invest. 2013;93:378-83.

8. Gambero A, Marostica M, Abdalla Saad MJ, Pedrazzoli J Jr. Mesenteric adipose tissue alterations resulting from experimental reactivated colitis. Inflamm Bowel Dis. 2007; 13:1357-64

9. Gillberg L, Varsanyi M, Sjöström M, Lördal M, Lindholm J, Hellström PM. Nitric oxide pathway-related gene alterations in inflammatory bowel disease. Scand $\mathbf{J}$ Gastroenterol. 2012;47:1283-97.

10. Grenz A, Clambey E, Eltzschig HK. Hypoxia signaling during intestinal ischemia and inflammation. Curr Opin Crit Care. 2012;18:178-85.

11. Han S, Wang G, Qi X, Lee HM, Englander EW, Greeley GH Jr. A possible role for hypoxia-induced apelin expression in enteric cell proliferation. Am J Physiol Regul Integr Comp Physiol. 2008;294:R1832-9.

12. Higashiyama M, Hokari R, Hozumi H, Kurihara C, Ueda T, Watanabe C, et al. Hif- 1 in $\mathrm{T}$ cells ameliorated dextran sodium sulfate-induced murine colitis. $\mathrm{J}$ Leukoc Biol. 2012;91:901-9.

13. Hindryckx P, De Vos M, Jacques P, Ferdinande L, Peeters H, Olievier K, et al Hydroxylase inhibition abrogates TNF-alpha-induced intestinal epithelial damage by hypoxia-inducible factor-1-dependent repression of FADD. J Immunol. 2010;185:6306-16.
14. Kaelin WG, Jr., Ratcliffe PJ. Oxygen sensing by metazoans: the central role of the hif hydroxylase pathway. Mol Cell. 2008;30:393-402.

15. Karhausen J, Furuta GT, Tomaszewski JE, Johnson RS, Colgan SP, Haase VH. Epithelial hypoxia-inducible factor-1 is protective in murine experimental colitis. J Clin Invest. 2004;114:1098-106.

16. Kozhukhar AV, Yasinska IM, Sumbayev VV. Nitric Oxide Inhibits HIF-1alpha protein accumulation under hypoxic conditions: implication of 2-oxoglutarate and iron. Biochimie. 2006;88:411-8.

17. Ljung T, Lundberg S, Varsanyi M, Johansson C, Schmidt PT, Herulf M, et al. Rectal nitric oxide as biomarker in the treatment of inflammatory bowel disease: responders versus nonresponders. World J Gastroenterol. 2006;12:3386-92.

18. Mateo J, Garcia-Lecea M, Cadenas S, Hernandez C, Moncada S. Regulation of hypoxia-inducible factor-1alpha by nitric oxide through mitochondria-dependent and -independent pathways. Biochem J. 2003;376:537-44.

19. Olson N, Van Der Vliet A. Interactions between nitric oxide and hypoxia-inducible factor signaling pathways in inflammatory disease. Nitric Oxide. 2011;25:125-37.

20. Rafa H, Saoula H, Belkhelfa M, Medjeber O, Soufli I, Toumi R, et al. IL-23/ IL-17A axis correlates with the nitric oxide pathway in inflammatory bowe disease: immunomodulatory effect of retinoic acid. J Interferon Cytokine Res. 2013;33:355-68.

21. Robinson A, Keely S, Karhausen J, Gerich ME, Furuta GT, Colgan SP. Mucosal protection by hypoxia-inducible factor prolyl hydroxylase inhibition. Gastroenterology. 2008; 134:145-55.

22. Rutella S, Fiorino G, Vetrano S, Correale C, Spinelli A, Pagano N, et al. Infliximab therapy inhibits inflammation-induced angiogenesis in the mucosa of patients with Crohn's disease. Am J Gastroenterol. 2011;106:762-70.

23. Shah Ym, Ito S, Morimura K, Chen C, Yim SH, Haase VH, Gonzalez FJ. Hypoxia-inducible factor augments experimental colitis through an mif-dependent inflammatory signaling cascade. Gastroenterology. 2008;134:2036-48, 2048.e1-3.

24. Sohn JJ, Schetter AJ, Yfantis HG, Ridnour LA, Horikawa I, Khan MA, et al. Macrophages, nitric oxide and microRNAs are associated with DNA damage response pathway and senescence in inflammatory bowel disease. PLoS One. 2012; 7:E44156.

25. Taylor Ct, Moncada S. Nitric Oxide, Cytochrome C Oxidase, and the cellular response to hypoxia. Arterioscler Thromb Vasc Biol. 2010;30:643-7. 